\title{
Sevoflurane reduces endothelium-dependent vasorelaxation: role of superoxide anion and endothelin
}

\author{
[Le sévoflurane réduit la vasorelaxation provenant de l'endothélium : le rôle de \\ l'anion superoxyde et de l'endothéline]
}

María M. Arriero PhD, Luis Muñoz Alameda MD, Antonio López-Farré PhD, Marta Escribano Burgos PhD, Carolina Carrasco PhD, Inmaculada Millás MS, Angel Celdrán MD, Juan Carlos de la Pinta MD

Purpose: There are several reports suggesting that volatile anesthetics alter vascular endothelial function. We analyzed the effect of sevoflurane, a fluorinated volatile anesthetic, on nitric oxide (NO)dependent relaxation, evaluating the role of the endotheliumderived vasoconstrictor endothelin-I (ET-I).

Methods: The experiments were performed in rat isolated aortic segments aerated in the absence and in the presence of sevoflurane (2\%).

Results: Acetylcholine-induced relaxation was reduced in aortic segments aerated with sevoflurane. Sevoflurane failed to modify relaxatation in response to an exogenous $\mathrm{NO}$ donor, sodium nitroprusside. Superoxide dismutase, a scavenger of superoxide anion, partially restored the impaired vasorelaxation induced by sevoflurane, an effect that was associated with the release of superoxide anion. The presence of BQ-123, an antagonist of endothelin ETAtype receptors, normalized the vasorelaxing response to acetylcholine in the presence of sevoflurane. In addition, BQ- 123 also reduced the ability of the sevoflurane-incubated vascular wall to release superoxide anion.

Conclusions: Our results suggest that sevoflurane impairs the endothelium-dependent vasorelaxation but that the endotheliumindependent response remains intact. ET-I and superoxide anion are involved in the endothelial dysfunction induced by sevoflurane. Further studies are needed to associate the endothelial dysfunction related to sevoflurane shown herein and its reported preconditioning properties on the myocardium.

Objectif : Certains articles suggèrent que les anesthésiques volatils modifient la fonction endothéliale vasculaire. Nous avons analysé l'effet du sévoflurane, un anesthésique volatil fluoré, sur la relaxation liée à l'oxyde nitrique (NO) en évaluant le rôle de l'endothéline-I (ET-I) vasoconstrictrice d'origine endothéliale.

Méthode : Les expériences ont été réalisées sur des segments aortiques isolés de rat aérés en l'absence et en présence de sévoflurane à $2 \%$.

Résultats : La relaxation induite par l'acétylcholine a été réduite dans les segments aérés avec le sévoflurane. Le sévoflurane n'a pas modifié la relaxation en réponse à un donneur de NO exogène, le nitroprussiate de sodium. La superoxyde dismutase, un piégeur de l'anion superoxyde, a partiellement restauré la vasorelaxation modifiée induite par le sévoflurane, un effet qui est associé à la libération de l'anion superoxyde. La présence de $B Q-123$, un antagoniste des récepteurs de type endothéline ETA, a normalisé la réponse vasorelaxante à l'acétylcholine en présence du sévoflurane. Le BQ- I23 a aussi réduit la capacité de la paroi vasculaire mise en incubation dans le sévoflurane à libérer l'anion superoxyde.

Conclusion : Nos résultats laissent croire que le sévoflurane affecte la vasorelaxation d'origine endothéliale mais que la réponse indépendante de l'endothélium demeure intacte. L'ET-I et l'anion superoxyde sont impliqués dans le dérèglement endothélial induit par le sévoflurane. D'autres études seront nécessaires pour pouvoir associer le dérèglement endothélial relié au sévoflurane démontré ici et ses propriétés mentionnées de préconditionnement sur le myocarde.

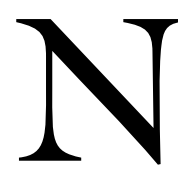
ITRIC oxide (NO) is a multifunctional molecule with an important role in the relationship between the cells that compose the microvascular environment. ${ }^{1-4}$ However, the first described effect of $\mathrm{NO}$ was its vasodilating property. $\mathrm{NO}$ is generated from the meta-

From the Cardiovascular Research and Hypertension Laboratory, Fundación Jiménez Díaz, Madrid, Spain. Address correspondence to: Dr. Juan C. de la Pinta, Cardiovascular Research and Hypertension Laboratory, Fundación Jiménez Díaz, Av Reyes Catolicos 2, Madrid 28040, Spain. Phone: 9155048 00; Fax: 9154947 64; E-mail: jcpinta@fjd.es Accepted for publication December 3, 2001.

Revision accepted January 31, 2002. 
bolic conversion of $\mathrm{L}$-arginine into $\mathrm{L}$-citrulline by the activity of the endothelial NO synthase. ${ }^{5}$ The NO generated by the endothelium provokes vasodilation by stimulating soluble guanylate cyclase in the adjacent vascular smooth muscle cells. ${ }^{1}$ Nitrovasodilators cause relaxation of vascular tissue independently of the endothelium by releasing $\mathrm{NO}$ and activating cyclic GMP formation in the smooth muscle cells. ${ }^{6}$ Superoxide anion inhibits the action of $\mathrm{NO}$ and this inhibition is attenuated by the concomitant application of superoxide dismutase (SOD) ${ }^{7,8}$

The endothelium also releases vasoconstrictor factors. Endothelin-1 (ET-1) is a potent vasoconstrictor peptide generated by endothelial cells that counterbalances the vasodilating effect of NO. ${ }^{9}$ Therefore, alterations in the endothelium-dependent relaxation could be associated not only with a defect in the NO/cGMP system but also with increased ET-1 release.

Sevoflurane is a fluorinated volatile anesthetic agent that provides rapid induction and recovery consistent with its low blood solubility. ${ }^{10,11}$ There are several reports suggesting that volatile anesthetics alter vascular endothelial function or the effect of endotheliumreleased vasodilating factors on vascular smooth muscle activity. In this regard, it has been demonstrated that isoflurane relaxed the vessels without endothelium more than the vessels with endothelium, suggesting that this volatile anesthetic may reduce the release of endothelium-derived relaxing factors or increase the release of endothelium-derived contracting factors. ${ }^{12}$ However, the role of ET- 1 in the effect of sevoflurane on the NO/cGMP relaxing system has not been investigated. Therefore, the aim of the present study was to analyze the effect of sevoflurane on the NO-dependent relaxation system. Moreover, the involvement of ET-1 and superoxide anion was also evaluated.

\section{Material and methods}

\section{Preparation for isometric tension measurements}

The study protocols were approved by the Institutional Ethics Committee for Animals and were performed according to the international conventions on animal experimentation.

Experiments were carried out using 30 male Wistar rats weighing $300 \pm 20 \mathrm{~g}$. The animals were anesthetized with pentobarbital $\left(30 \mathrm{mg} \cdot \mathrm{kg}^{-1} \mathrm{im}\right)$ and the descending thoracic aorta was removed to test the endothelium-dependent response to acetylcholine (Ach) and the endothelium-independent response to sodium nitroprusside (SNP).

Thoracic aortic segments were cut into portions of $2 \mathrm{~mm}$ in length and were suspended in Krebs-
Henseleit's solution (in $\mathrm{mmol} \cdot \mathrm{L}^{-1}: \mathrm{NaCl} 115, \mathrm{KCl}$ 4.6, $\mathrm{KH}_{2} \mathrm{PO}_{4} 1.2, \mathrm{MgSO}_{4} 1.2, \mathrm{CaCl}_{2} 2.5, \mathrm{NaHCO}_{3}$ 25 , glucose 11.1 and calcium sodium EDTA $0.02 \mathrm{pH}$ 7.4) at $37^{\circ} \mathrm{C}$. The organ bath contained $5 \mathrm{~mL}$ of the solution aerated with $95 \% \mathrm{O}_{2} / 5 \% \mathrm{CO}_{2}$ or a mixture containing sevoflurane. Sevoflurane was delivered using a calibrated agent-specific vaporizer (Abbot, France). The concentration of sevoflurane in the resulting gas mixture was monitored continuously by a precalibrated multi-gas anesthetic agent analyzer (Datex Capnomac, Helsinki, Finland). The mean bath anesthetic concentration after equilibration on aortic segment preparations was $2 \%$ sevoflurane. Aortic segments were connected to isometric force displacement transducers coupled to a computer system (Power Lab 400, AD Instruments, Casterhill, NSW, Australia). The segments were allowed to rest to the previously determined optimal resting force of $2 \mathrm{~g}$, as determined by repeated exposure to $20 \mathrm{mmol} \cdot \mathrm{L}^{-1} \mathrm{KCl}$. The endothelium-dependent relaxation to $\mathrm{Ach}$ and the endothelium-independent relaxation to SNP were tested on arteries precontracted with $10^{-5} \mathrm{~mol} \cdot \mathrm{L}^{-1}$ phenylephrine as reported previously. ${ }^{13}$ The doseresponse curves were determined in a cumulative manner. All the experiments were performed in the presence of indomethacin $\left(10^{-5} \mathrm{~mol} \cdot \mathrm{L}^{-1}\right)$ to block any effect mediated by the activation of cyclooxygenase which could hide the NO-related effects.

Additional experiments were done in the presence and in the absence of the superoxide anion scavenger, superoxide dismutase, and with the endothelin-type A receptor antagonist $\mathrm{BQ}-123\left(10^{-6} \mathrm{~mol} \cdot \mathrm{L}^{-1}\right)$.

\section{Superoxide anion generation}

The amount of superoxide anion generated by the aortic segments was determined by measuring the SOD-inhibitable reduction of ferricytochrome C. In brief, aortic rings were placed in a water bath at $37^{\circ} \mathrm{C}$ in the above- described Krebs-Henseleit's solution containing $0.1 \mathrm{mmol} \cdot \mathrm{L}^{-1}$ ferricytochrome $\mathrm{C}$ and incubated for $30 \mathrm{~min}$ in the presence and in the absence of $2 \%$ sevoflurane. The generation of superoxide anion was calculated as the difference in absorbance between aortic rings incubated with and without SOD (400 $\left.\mathrm{U} \cdot \mathrm{mL}^{-1}\right)$. The difference was then divided by the molar extinction coefficient change between ferricytochrome $\mathrm{C}$ and ferrocytochrome $\mathrm{C}$ to determine nmoles of superoxide radicals produced over $30 \mathrm{~min}$. All observations were made in triplicate and the data averaged. The absorbance was measured in a spectrophotometer at $550 \mathrm{~nm}$. 


\section{Statistical methods}

Results are expressed as mean \pm SEM. Each of the above mentioned studies was performed in a minimum of ten different aortic segments. Comparisons were performed by ANOVA. Bonferroni's correction for multiple comparisons was used to determine the level of significance of the $P$ value. $P<0.05$ was considered significant.

\section{Results}

\section{Vasorelaxation studies}

Ach produced a dose-related relaxation in phenylephrine-precontracted aortic rings from controls (Figure 1A). Relaxation to Ach was significantly reduced in sevoflurane-incubated aortic rings (Figure $1 \mathrm{~A}$ ). The $\mathrm{EC}_{50}$ for control vascular segments was $1 \times 10^{-8} \pm 1.1$ $\mathrm{mol} \cdot \mathrm{L}^{-1}$ and the $\mathrm{EC}_{50}$ for $2 \%$ sevoflurane-incubated segments was $1.8 \times 10^{-7} \pm 0.2 \mathrm{~mol} \cdot \mathrm{L}^{-1}(\mathrm{P}<0.05)$. The $\mathrm{EC}_{50}$ values were taken from individual fits to data from each experiment. Four percent sevoflurane more markedly reduced Ach-induced relaxation than 2\% sevoflurane suggesting a dose-dependent effect of sevoflurane (Figure 1A). The $\mathrm{EC}_{50}$ for $4 \%$ sevofluraneincubated segments was $5.3 \times 10^{-7} \pm 0.6 \mathrm{~mol} \cdot \mathrm{L}^{-1}(P<$ 0.05 with respect to control). A greater maximum response to Ach was also observed in control aortic rings than in $2 \%$ and $4 \%$ incubated aortic segments (Figure 1A). Removal of the endothelium from the aorta by gentle rubbing completely prevented the relaxing response to Ach in both control and 2\% and 4\% sevoflurane-incubated aortic segments (Figure 1B). The endothelium-independent relaxation, as evaluated by the SNP-induced dose-response relaxation, was similar in control and in $2 \%$ and $4 \%$ sevoflurane-treated aortic rings (Figure $1 \mathrm{C}$ ).

\section{Involvement of ET-1 in the endothelial dysfunction induced by sevoflurane}

We further analyzed the mechanism involved in the endothelial dysfunction induced by sevoflurane. For this purpose we used a submaximal dose of sevoflurane $(2 \%)$ to facilitate the reversion of the effects elicited by sevoflurane. Since superoxide anions are important to accelerate the catabolism of $\mathrm{NO}$, further experiments were performed on $2 \%$ sevoflurane-incubated aortic rings in the presence of the superoxide anion scavenger SOD. Addition of $200 \mathrm{U} \cdot \mathrm{mL}^{-1}$ SOD partially prevented the impaired relaxation to $10^{-4}$ mol. $\mathrm{L}^{-1}$ Ach induced by sevoflurane (Figure 2). Higher doses of SOD (300 and $400 \mathrm{U} \cdot \mathrm{mL}^{-1}$ ) did not enhance the effect obtained with $200 \mathrm{U} \cdot \mathrm{mL}^{-1}$ SOD on the Ach-dependent relaxation (Figure 2). The addition of $400 \mathrm{U} \cdot \mathrm{mL}^{-1}$ SOD to control vascular seg-
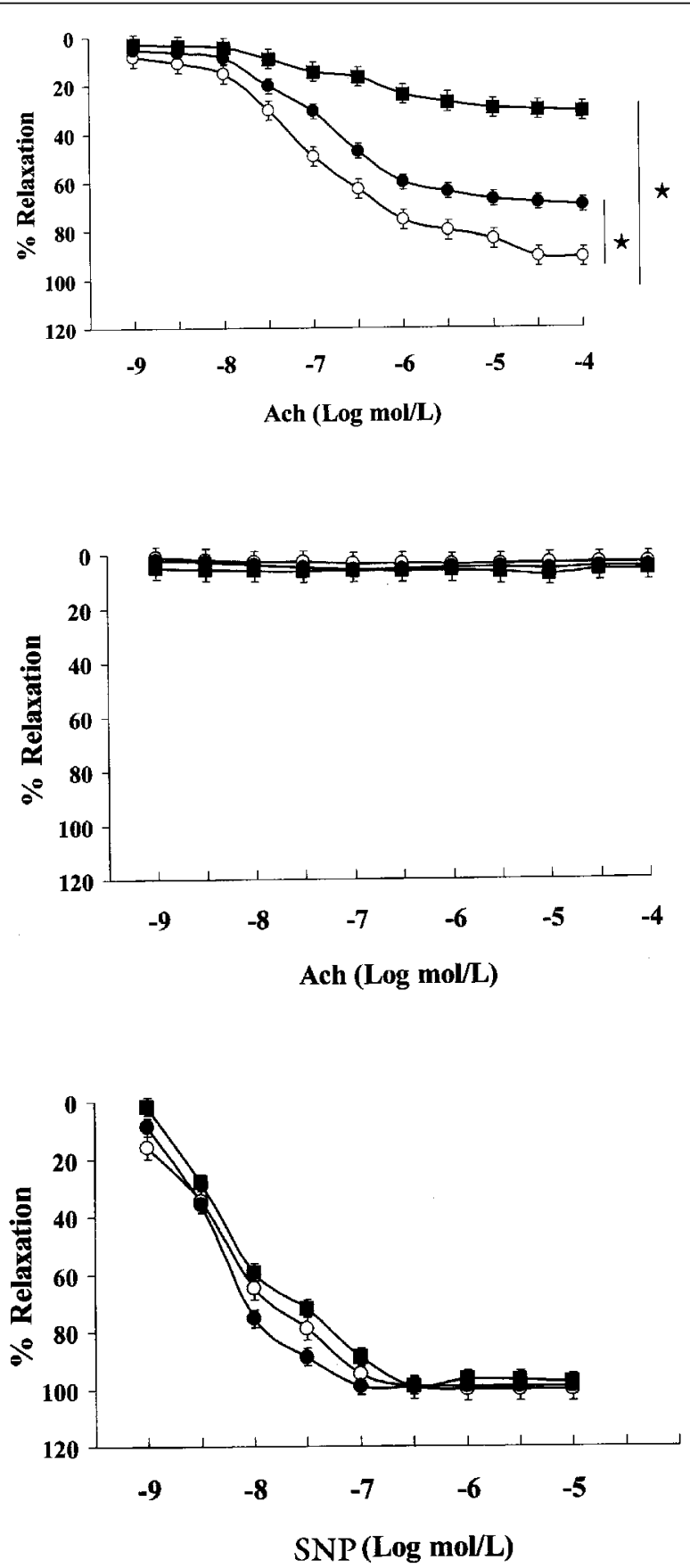

FIGURE 1 Graph showing vascular relaxation by acetylcholine (Ach) in the presence (A) and in the absence (B) of endothelium in control (open circles) and $2 \%$ (closed circles and $4 \%$ closed squares) sevoflurane-treated rat isolated aortic rings. The vascular relaxation to sodium nitroprusside is also shown (C). Results are expressed as percent relaxation with respect to contraction by phenylephrine $\left(10^{-5} \mathrm{~mol} \cdot \mathrm{L}^{-1}\right)$. Results are represented as mean \pm SEM of ten different aortic segments. ${ }^{*} P<0.05$ with respect to the Ach response curve in control segments. 


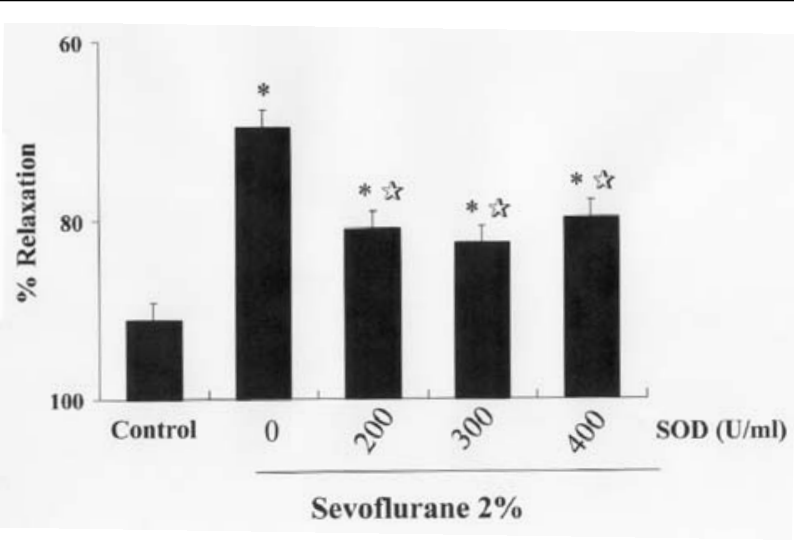

FIGURE 2 Bar graph showing vascular relaxation by $10^{-4} \mathrm{~mol} \cdot \mathrm{L}^{-1}$ acetylcholine (Ach) in control and sevoflurane (2\%)treated rat isolated aortic segments. The effect of the superoxide anion scavenger, superoxide dismutase (SOD), was analyzed. Results are expressed as percent relaxation with respect to contraction by phenylephrine $\left(10^{-5} \mathrm{~mol} \cdot \mathrm{L}^{-1}\right)$. Results are represented as mean \pm SEM of ten different aortic segments. ${ }^{*} P<0.05$ with respect to control segments. is $P<0.05$ with respect to sevoflurane-treated segments in the absence of SOD.

ments failed to modify the relaxing response to Ach $\left(\mathrm{EC}_{50}: 5.0 \times 10^{-8} \pm 0.08 \mathrm{~mol} \cdot \mathrm{L}^{-1} ; P=\mathrm{NS}\right.$ with respect to control segments).

Then we attempted to evaluate the involvement of ET- 1 in the above-mentioned impaired endotheliumdependent relaxation elicited by sevoflurane. Incubation of isolated aortic segments with BQ-123 $\left(10^{-6} \mathrm{~mol} \cdot \mathrm{L}^{-1}\right)$, an ETA-type receptor antagonist, normalized the relaxation induced by Ach in aortic segments exposed to sevoflurane (Figure 3). BQ-123 failed to modify the relaxing response to Ach in control segments (Figure 3).

Two percent sevoflurane stimulated the ability of isolated aortic segments to release superoxide anion (control: $1.06 \pm 0.03 \mu \mathrm{g} \cdot \mathrm{mg}^{-1}$ protein; sevoflurane: $2.1 \pm 0.05 \mu \mathrm{g} \cdot \mathrm{mg}^{-1}$ protein; $\left.P<0.05\right)$. The presence of BQ-123 reduced the amount of superoxide anion released from sevoflurane-incubated aortic segments $\left(1.54 \pm 0.06 \mu \mathrm{g} \cdot \mathrm{mg}^{-1}\right.$ protein; $P<0.05$ with respect to sevoflurane-treated aortic segments). However, the ability of the vascular wall to release superoxide anion remained significantly elevated with respect to control aortic rings $(P<0.05)$. No additional effects on sevoflurane-induced superoxide anion release were obtained with higher concentrations of BQ-123 $\left(10^{-5}\right.$ $\mathrm{mol} \cdot \mathrm{L}^{-1}$ and $\left.10^{-4} \mathrm{~mol} \cdot \mathrm{L}^{-1}\right)$.

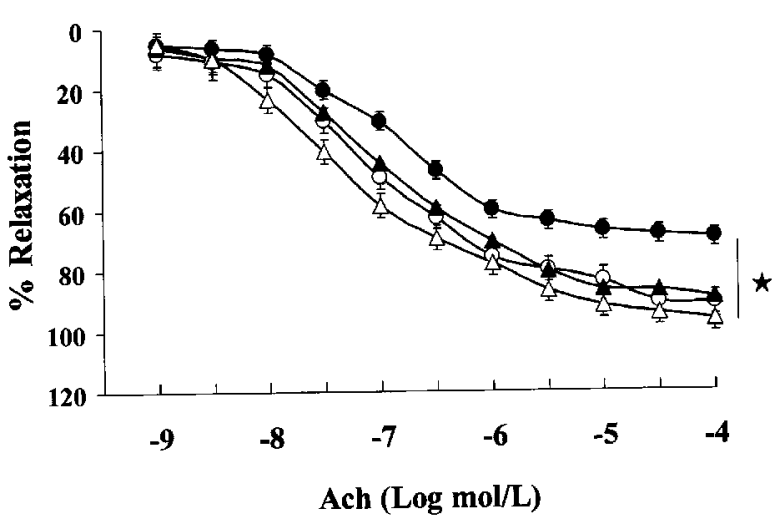

FIGURE 3 Graph showing vascular relaxation by $10^{-4} \mathrm{~mol} \cdot \mathrm{L}^{-1}$ acetylcholine (Ach) in control (open circles) and sevoflurane (2\%)treated (closed circles) rat isolated aortic segments in the presence and in the absence of the ETA-type receptor antagonist, BQ-123 $\left(10^{-6} \mathrm{~mol} \cdot \mathrm{L}^{-1}\right.$; for sevoflurane $+\mathrm{BQ}-123$, closed triangles; for control + BQ-123 open triangles). Results are expressed as percent relaxation with respect to contraction by phenylephrine $\left(10^{-5} \mathrm{~mol} \cdot \mathrm{L}^{-1}\right)$. Results are represented as mean \pm SEM of ten different aortic segments. ${ }^{*} \mathrm{P}<0.05$ with respect to control segments.

\section{Discussion}

We have shown that sevoflurane impairs, in a dose dependent manner, the endothelium-dependent vasorelaxation to Ach but does not modify the endothelium-independent relaxing response to an exogenous NO-donor, SNP. These results suggest that the effect of sevoflurane is located somewhere along the pathway leading from Ach signalling to the transduction of NO from the endothelium to smooth muscle cells.

In accordance with our results Yamaguchi et al. have also demonstrated that $2 \%$ sevoflurane attenuated the endothelium-dependent relaxation, an effect that has been more markedly observed by other authors with $4 \%$ sevoflurane although the involved mechanisms were not completely established. ${ }^{14-16}$

NO is degraded by free radicals, particularly by superoxide anion. We then determined the effect of sevoflurane on the ability of the vascular wall to release superoxide anion. Sevoflurane increased the release of superoxide anion by the vascular wall. However, although the superoxide anion scavenger SOD significantly improved the Ach-dependent relaxation, it remained reduced with respect to control aortic segments. These results indicate that superoxide anion is involved in the effect of sevoflurane on endothelial functionality although additional factors should be implicated. 
Endothelial dysfunction can occur not only because of a lack of the NO/cGMP-dependent vasodilating system, but also because of an increased release of vasoconstrictor agents. In this regard, the endothelium is the source of the potent vasoconstrictor, ET-1, which has been reported to be increased during surgery. ${ }^{9,17}$ ET-l is a 2l-aminoacid peptide that binds to ETA-type receptors expressed on smooth muscle cells inducing a vasoconstrictor response. ${ }^{18,19}$ Interestingly, ET-1 is also capable of stimulating the production of superoxide anion by several types of cells. ${ }^{20,21}$

In our study, a specific antagonist of the ETA-type receptors, $\mathrm{BQ}-123$, normalized the endotheliumdependent vasorelaxing response impaired by sevoflurane suggesting that vasoconstriction related to ET- 1 could be counterbalancing the NO-dependent vasorelaxing system in sevoflurane-incubated aortic segments. It has been also reported that ET-l reduces the ability of the endothelium to release $\mathrm{NO}^{22}$

Several reports are in accordance with our results. Izumi et al. have reported recently that, in the presence of endothelium, sevoflurane enhanced the contractile response to norepinephrine in isolated mesenteric arteries. ${ }^{23}$ This could be related to the reduction of the NO-dependent vasorelaxing response secondary to ET-1 release that we have shown. Different studies have also postulated that volatile anesthetics such as halothane, isoflurane and even sevoflurane attenuated the endothelium-dependent relaxation. ${ }^{24-26}$

The fact that sevoflurane reduced the NO-dependent relaxation may be explained by a possible binding activity of sevoflurane to $\mathrm{NO}$, avoiding the action of NO on smooth muscle cells. However, a recent study has shown the inability of sevoflurane to interact chemically with $\mathrm{NO}$ and its ability to inhibit NO production directly in endothelial cells. ${ }^{27}$

The originality of our study lies in the demonstration of the involvement of ET-1 in sevofluraneinduced endothelial dysfunction. Blockade of ETA-receptors by BQ-123 completely reverted the impaired vasorelaxing response to Ach in sevofluranetreated aortic segments. This rules out a possible direct effect of sevoflurane on Ach receptors.

It is noteworthy that BQ-123 reduced superoxide anion production by sevoflurane-treated aortic segments although the superoxide anion production remained elevated with respect to control vessels. These results suggest that the stimulation of superoxide anion production by sevoflurane was only partially dependent of ET-1. Further studies are needed to elucidate other mechanisms by which sevoflurane induced superoxide anion generation by the vascular wall.
A reduction in endothelium-dependent vaxorelaxation by either a defect in the NO system and/or an increase in the production of endothelium-derived vasoconstrictors, i.e., ET-1, could compromise the protective ability of the endothelium not only against vasoconstriction but also against thrombosis and leukocyte adhesion as occurs in myocardial ischemia. ${ }^{3,28}$ We have to keep in mind the anti-platelet and leukocyte activation properties of NO and the opposite effects of ET-1 on platelets and leukocyte activation. ${ }^{1,3,29}$ Several studies have suggested that volatile anesthetics mimic ischemic preconditioning of the myocardium. ${ }^{30}$ Further studies are warranted to correlate the effects of sevoflurane shown herein on endothelial functionality and its reported preconditioning properties on the myocardium.

A limitation of the present study may be its in vitro character. Clinically, sevoflurane administration has the effect of lowering blood pressure, presumably in part by vasodilation. In our study we only analyzed the direct effect of sevoflurane on the NO-dependent relaxing system in the vascular wall. However, in in vivo conditions sevoflurane may act both centrally and peripherally, attenuating neuronal excitatory activity and producing a systemic vasodilating action. In this regard, it was recently reported that sevoflurane inhibited norepinephrine outflow from the nerve terminals. ${ }^{31}$

In summary, our results suggest that ET-1 is involved in the endothelial dysfunction induced by sevoflurane. This endothelial dysfunction may have clinical implications, specially with regard to mechanisms involved in the reported preconditioning properties of sevoflurane on the myocardium.

\section{Acknowledgements}

This work was supported by grants from Dirección General de Investigación Científica y Técnica (SAF 2000- 0024) and Fondos FEDER (2FD97-1531). M.M. Arriero and M. Escribano are fellows from Fundación Conchita Rábago de Jiménez Díaz. The authors thank Begoña Larrea for secretarial assistance.

\section{References}

1 Moncada S, Palmer RMJ, Higgs EA. Nitric oxide: physiology, pathophysiology, and pharmacology. Pharmacol Rev 1991; 43: 109-42.

2 Moncada S, Higgs A. The L-arginine-nitric oxide pathway. N Engl J Med 1993; 329: 2002-12.

3 López-Farré A, Caramelo C, Esteban A, et al. Effects of aspirin on platelet-neutrophil interactions. Role of nitric oxide and endothelin-1. Circulation 1995; 91 : $2080-8$.

4 Trachtman H, Futterweit S, Singhal P. Nitric oxide modulates the synthesis of extracellular matrix proteins 
in cultured rat mesangial cells. Biochem Biophys Res Commun 1995; 207: 120-5.

5 Sessa WC. The nitric oxide synthase family of proteins. J Vasc Res 1994; 31: 131-43.

6 Katsuki S, Arnold W, Mittal C, Murad F. Stimulation of guanylate cyclase by sodium nitroprusside, nitroglycerine and nitric oxide in various tissue preparations and comparison to the effects of sodium azide and hydroxilamine. J Cyclic Nucleotide Res 1977; 3: 23-35.

7 Moncada S, Palmer RMJ, Gryglewski RJ. Mechanism of action of some inhibitors of endothelium-derived relaxing factor. Proc Natl Acad Sci USA 1986; 83: 9164-8.

8 López-Farré A, Riesco A, Digiuni E, et al. Aspirin-stimulated nitric oxide production by neutrophils after acute myocardial ischemia in rabbits. Circulation 1996; 94: 83-7.

9 Yanagisawa $M$, Kurihara $H$, Kimura $S$, et al. A novel potent vasoconstrictor peptide produced by vascular endothelial cells. Nature 1988; 332: 411-5.

10 Wallin RF, Regan BM, Napoli MD, Stern IJ. Sevoflurane: a new inhalational anesthetic agent. Anesth Analg 1975; 54: 758-66.

11 Holaday DA, Smith FR. Clinical characteristics and biotransformation of sevoflurane in healthy human volunteers. Anesthesiology 1981; 54: 100-6.

12 Stone DJ, Johns RA. Endothelium-dependent effects of halothane, enflurane, and isoflurane on isolated rat aortic vascular rings. Anesthesiology 1989; 71: 126-32.

13 Gallego MJ, García-Villalón AL, López Farré AJ, et al. Mechanisms of the endothelial toxicity of cyclosporin A. Role of nitric oxide, cGMP, and $\mathrm{Ca}^{2+}$. Circ Res 1994; 74: 477-84.

14 Yamaguchi A, Okabe E. Effect of sevoflurane on the vascular reactivity of rabbit mensenteric artery. $\mathrm{Br} \mathrm{J}$ Anaesth 1995; 74: 576-82.

15 Yoshida K, Okabe E. Selective impairment of endothelium-dependent relaxation by sevoflurane: oxygen free radicals participation. Anesthesiology 1992; 76: 440-7.

16 Nakamura K, Terasako K, Toda H, et al. Mechanisms of inhibition of endothelium-dependent relaxation by halotane, isoflurane and sevoflurane. Can J Anaesth 1994; 41: 340-6.

17 Hirata $\Upsilon$, Itoh K-I, Ando K, Endo M, Marumo F. Plasma endothelin levels during surgery (Letter). N Engl J Med 1989; 321: 1686.

18 Pollock DM, Keith TL, Highsmith RF. Endothelin receptors and calcium signaling. FASEB J 1995; 9: 1196-204.

19 Lin $\Upsilon$, Geisbubler B, Jones AW. Activation of multiple mechanisms including phospholipase $\mathrm{D}$ by endothelin1 in rat aortic. Am J Physiol 1992; 262: C941-9.

20 Haller H, Schaberg T, Lindschan C, Lode H, Distler A. Endothelin increases $\left[\mathrm{Ca}^{2+}\right]_{\mathrm{i}}$, protein phosphorylation, and $\mathrm{O}_{2}$ - production in human alveolar macrophages. Am J Physiol 1991; 261: L478-84.

21 Bugajski P, Kalawski R, Balinski $M$, et al. Plasma-mediated stimulation of neutrophil superoxide anion production during coronary artery bypass grafting: role of endothelin-1. Thorac Cardiovasc Surg 1999; 47 : 144-7.

22 Boulanger $C$, Lüscher TF. Release of endothelin from the porcine aorta. Inhibition by endothelium-derived nitric oxide. J Clin Invest 1990; 85: 587-90.

23 Izumi K, Akata T, Takahashi S. The action of sevoflurane on vascular smooth muscle of isolated mesenteric resistance arteries (part 1). Anesthesiology 2000; 92: 1426-40.

24 Toda H, Nakamura K, Hatano $\Upsilon$, Nishiwada M, Kakuyama M, Mori K. Halothane and isoflurane inhibit endothelium-dependent relaxation elicited by acetylcholine. Anesth Analg 1992; 75: 198-203.

25 Muldoon SM, Hart JL, Bowen KA, Freas $W$. Attenuation of endothelium-mediated vasodilation by halothane. Anesthesiology 1988; 68: 31-7.

26 Az-ma T, Fujii K, Yuge O. Inhibitory effect of sevoflurane on nitric oxide release from cultured endothelial cells. Eur J Pharmacol 1995; 289: 33-9.

27 Dinerman JL, Mehta JL. Endothelial, platelet and leukocyte interactions in ischemic heart disease: insights into potential mechanisms and their clinical relevance. J Am Coll Cardiol 1990; 16: 207-22.

28 Pearson PJ, Schaff HV, Vanhoutte PM. Acute impairment of endothelium-dependent relaxations to aggregating platelets following reperfusion injury in canine coronary arteries. Cir Res 1990; 67: 385-93.

29 Kersten JR, Orth KG, Pagel PS, Mei DA, Gross GJ, Warltier DC. Role of adenosine in isoflurane-induced cardioprotection. Anesthesiology 1997; 86: 1128-39.

30 Buljubasic N, Marijic J, Stowe DF, Kampine JP, Bosnjak ZJ. Halothane reduces dysrhythmias and improves contractile function after global hypoperfusion in isolated hearts. Anesth Analg 1992; 74: 384-94.

31 Yamazi M, Stekiel TA, Bosnjak ZJ, Kampine JP, Stekiel $W J$. Effect of volatile anesthetic agents on in situ vascular smooth muscle transmembrane potential in resistance-and capacitance-regulating blood vessels. Anesthesiology 1998; 88: 1085-95. 